\title{
Influence of deep cryogenic treatment of high speed steel substrate on TiAIN coating properties
}

\author{
Einfluss der kryogenischen Behandlung eines Substrates aus \\ Schnellarbeitsstahl auf die Eigenschaften der TiAIN Beschichtung
}

\author{
S. Šolić1 ${ }^{1}$ F. Cajner ${ }^{1}$, P. Panjan²
}

Deep cryogenic treatment in combination with classic heat treatment shows a significant improvement in wear resistance of high speed steel tools. The aim of this research was to investigate how the microstructure of the substrate tool steel material, which was altered by deep cryogenic treatment and plasma nitriding, influences the properties of TiAIN coating.

The microstructure, topography and composition of the TiAIN coating were investigated using field-emission scanning electron microscope, atomic force microscopy, XRD, and glow discharge optical emission spectroscopy. The coating adhesion was measured using the scratch test. The sliding wear resistance and the force required to break the coating were determined with the ball-on-flat method. Resistance to microabrasion was measured by free ball abrasion test.

The results show that deep cryogenic treatment combined with plasma nitriding influence the adhesion of the TiAIN coating to the high speed steel substrate. Wear resistance tests show better wear resistance of deep cryogenic treated samples in comparison with conventionally heat treated ones.

Keywords: deep cryogenic treatment / plasma nitriding / PVD TiAIN coating / abrasive wear resistance

Die kryogenische Behandlung in Kombination mit der klassischen Behandlung zeigt eine wesentliche Verbesserung der Verschleißfestigkeit von Hochgeschwindigkeits-Werkzeugen an. Das Ziel dieser Arbeit war die Untersuchung der Mikrostrukturauswirkung des Werkzeugstahlsubstrats, das mit der kryogenischen Behandlung und mit dem Plasmanitrieren modifiziert wurde, auf die Eigenschaften der TiAIN Beschichtung zu zeigen.

Die Mikrostruktur, die Topographie und die Zusammensetzung der TiAIN Beschichtung wurde mit FE, SEM, atomic force microscopy, XRD und glow discharge optical emission spectroscopy untersucht und analysiert. Die quantitative Beurteilung der Beschichtungsadhäsion wurde mit der Ritzprüfung durchgeführt. Der Gleitverschleiß und die benötigte Kraft mit der man die Beschichtung zerstören kann, waren mit der „Ball-on-Flat“ Methode geprüft. Der Mikroabrasionswiderstand wurde mit dem Kalottenschliffverfahren gemessen.

Die Resultate zeigen, dass die kryogenische Behandlung in Kombination mit dem Plasmanitrieren einen Einfluss auf die Adhäsion der TiAIN Beschichtungen an dem Hochgeschwindigkeits-Substrat hat. Die Gleitverschleißprüfungen zeigen bessere Resultate der kryogenisch behandelten Proben gegenüber den konventionell behandelten Proben.

Schlüsselwörter: kryogenische Behandlung / Plasmanitrieren / PVD TiAIN Beschichtung / Charakterisierung / Gleitverschleißwiederstand

\section{Introduction}

Longer lifetime of cutting and forming tools is achieved by applying hard coatings. The main advantage of coatings is the

\footnotetext{
${ }^{1}$ Faculty of Mechanical Engineering and Naval Architecture, Zagreb, Croatia

${ }^{2}$ Jožef Stefan Institute, Ljubljana, Slovenia
}

Corresponding author: Sanja Šolić, University of Zagreb, Faculty of Mechanical Engineering and Naval Architecture, I. Lučića 1, 10000 Zagreb, Croatia

E-mail: sanja.solic@fsb.hr improved wear resistance due to the high hardness, which gives a good resistance to abrasive wear and high chemical stability, resulting in a high resistance to solution wear. An increased production rate can be achieved in cutting with coated tools because increased cutting speeds, feeds and depths of cut can be used. The cutting mechanism is improved and results in a lower cutting force and improved surface finish. Due to the chemical stability of coatings which represent a diffusion barrier, diffusion wear is also reduced.

In order to ensure longer lifetime of the tool, the coating material must have a low level of sticking to the work piece material and a high level of adhesion to the tool material, it must have 
Table 1. Chemical composition of the tested PM S390 MC steel (Böhler) [wt.-\%]

Tabelle 1. Chemische Zusammensetzung der untersuchten PM S390 MC Stähle (Böhler) [Gew.-\%]

\begin{tabular}{lllllllll}
\hline$\% \mathrm{C}$ & $\% \mathrm{Si}$ & $\% \mathrm{Mn}$ & $\% \mathrm{Cr}$ & $\% \mathrm{Mo}$ & $\% \mathrm{~V}$ & $\% \mathrm{~W}$ & $\% \mathrm{Co}$ & $\% \mathrm{Fe}$ \\
\hline 1.64 & 0.60 & 0.30 & 4.80 & 2.00 & 4.80 & 10.40 & 8.00 & remainder \\
\hline
\end{tabular}

Table 2. Heat treatment parameters and surface hardness after heat treatment

Tabelle 2. Die Parameter der Wärmebehandlung und resultierende Härtewerte

\begin{tabular}{|c|c|c|c|c|c|}
\hline Specimen & $\begin{array}{l}\text { Austenizing } \\
{ }^{\circ} \mathrm{C} / \mathrm{min}\end{array}$ & $\begin{array}{l}\text { Deep-Cryogenic } \\
\text { Treatment } \\
{ }^{\circ} \mathrm{C} / \mathrm{h}\end{array}$ & $\begin{array}{l}\text { Tempering } \\
{ }^{\circ} \mathrm{C} / \mathrm{h}\end{array}$ & $\begin{array}{l}\text { Nitriding } \\
{ }^{\circ} \mathrm{C} / \mathrm{h}\end{array}$ & HV 1 \\
\hline $\mathbf{P 2}$ & $1130 / 6$ & - & $520 / 520 / 490 / 2 h$ & - & $917 \pm 40$ \\
\hline P3 & $1130 / 6$ & - & $520 / 520 / 490 / 2 \mathrm{~h}$ & $490 / 2.5$ & $1427 \pm 65$ \\
\hline DH2 & $1130 / 6$ & $-196 / 24$ & $520 / 2 h$ & - & $945 \pm 40$ \\
\hline DH3 & $1130 / 6$ & $-196 / 24$ & $520 / 2 h$ & $490 / 2.5$ & $1352 \pm 60$ \\
\hline
\end{tabular}

good resistance to abrasive wear, high chemical stability and high hot hardness. Further requirements on the coating are a small grain size, internal compressive stresses, and a smooth surface [1-3].

Investigations carried out so far have shown that the adhesive joint (the coating/substrate interface) plays a major role in the efficiency of the substrate/coating/workpiece tribo-system $[4,5]$. The high adhesion directly influences the effectiveness of hard coating in tribological contact with the workpiece material. If adhesion is not sufficient, all other properties of the coating will not come to the fore. The quality of adhesive joint between the substrate and the coating is enhanced by improving the properties of substrate material, and by a change in microstructure.

Characteristics of coatings (thickness, chemical composition, microstructure, topography, etc.) are determined by the coating deposition parameters (temperature of substrate, characteristics of plasma, etch duration, substrate bias etc.) and by the properties of the substrate material (chemical composition, microstructure, topography, etc.) $[6,7,8]$. The substrate material primarily influences the nucleation and the growth of coating as well as the coating topography. Therefore, the substrate material and its surface pretreatment (purity, roughness) are of major importance for the topography and adhesion of the coating. Furthermore all mechanical, thermal, chemical and tribological properties of the coating depend on its thickness, chemical composition, microstructure, etc.

Application of deep cryogenic treatment in the heat treatment of high speed steel tools has resulted in increased wear resistance and dimensional stability of treated material $[9,10]$. Deep cryogenic treatment applied before tempering eliminates residual austenite but also stimulates the nanoscale $\eta$-carbide precipitation throughout the tool volume [11]. The high hardness and internal compressive stresses of the case formed by plasma nitriding can lead to increased load carrying capacity, as well as to improve coating adhesion, fatigue strength and tribological properties of the coated parts.

The aim of this work is to investigate the influence of deep cryogenic treatment and plasma nitriding of the high speed steel substrates on the adhesion of TiAlN coating.

\section{Description of the experiment}

\subsection{Materials and performed treatments}

Powder metallurgy high-speed steel (PM S390 MC, Boehler) was used as the substrate material. The steel was delivered in the annealed condition as a round bar $\varnothing 22 \mathrm{~mm}$. Chemical composition of the steel is given in Table 1 .

Disc-shaped specimens with dimensions of $\varnothing 22 \times 4 \mathrm{~mm}$ were cut from the bar. The specimens were heat treated in a vacuum furnace. They were pre-heated at $650^{\circ} \mathrm{C}$ for $30 \mathrm{~min}$, at $850^{\circ} \mathrm{C}$ for $20 \mathrm{~min}$, and at $1050^{\circ} \mathrm{C}$ for $15 \mathrm{~min}$. Subsequently, the specimens were austenized for $6 \mathrm{~min}$ at $1130^{\circ} \mathrm{C}$. Quenching was carried out in the nitrogen gas flow at $p=1050$ mbar. After quenching to room temperature, a part of specimens were very slowly immersed into liquid nitrogen $\left(-196^{\circ} \mathrm{C}\right)$ for $24 \mathrm{~h}$ and the rest of the specimens were immediately tempered in vacuum two times at $520^{\circ} \mathrm{C} / 2 \mathrm{~h}$, and the third time at $490^{\circ} \mathrm{C}$ for $2 \mathrm{~h}$. After $24 \mathrm{~h}$ in liquid nitrogen specimens were very slowly heated to room temperature and tempered at $520^{\circ} \mathrm{C}$ for $2 \mathrm{~h}$ in a vacuum furnace. After the heat treatment had been completed, a part of specimens were plasma nitrided. Nitriding was carried out in a Metalplast Ionon device, BDAG GRUPPE BALCKE-DÜRR AG. The composition of gases was $95 \% \mathrm{H}_{2}$ and $5 \% \mathrm{~N}_{2}$. The nitriding process took place at a temperature of $490^{\circ} \mathrm{C}$ and lasted $2.5 \mathrm{~h}$. Heat treatment and nitriding parameters with achieved substrate surface hardness are shown in Table 2.

After the heat treatment the microstructure of the HSS substrates had two types of primary carbides approx. $1 \mu \mathrm{m}$ in diameter, evenly dispersed in a matrix of plate martensite, lighter $\mathrm{M}_{6} \mathrm{C}$ tungsten carbides $\left(\mathrm{Fe}_{6} \mathrm{~W}_{6} \mathrm{C}\right)$ and darker $\mathrm{MC}$ vanadium carbides (VC). Using the IMAGE J program, the volume fraction of carbides was estimated to $12.7 \pm 0.8 \%$ for MC carbides (darker) and to $4.2 \pm 0.3 \%$ for $\mathrm{M}_{6} \mathrm{C}$ carbides (lighter) [12]. All substrates were polished to a mirror finish with the mean values of roughness of $R_{a}=9.3 \mathrm{~nm}$ and $R_{z}=75.6 \mathrm{~nm}$ before coating. The TiAlN coating was prepared in a sputter source CemeCom CC800/7. In the vacuum chamber they were heated to about $450^{\circ} \mathrm{C}$ and then in-situ cleaned by ion etching. During deposition, a bias voltage of $-80 \mathrm{~V}$ was applied. The whole PVD process lasted $9000 \mathrm{~s}$ (2.5 h). Dur- 

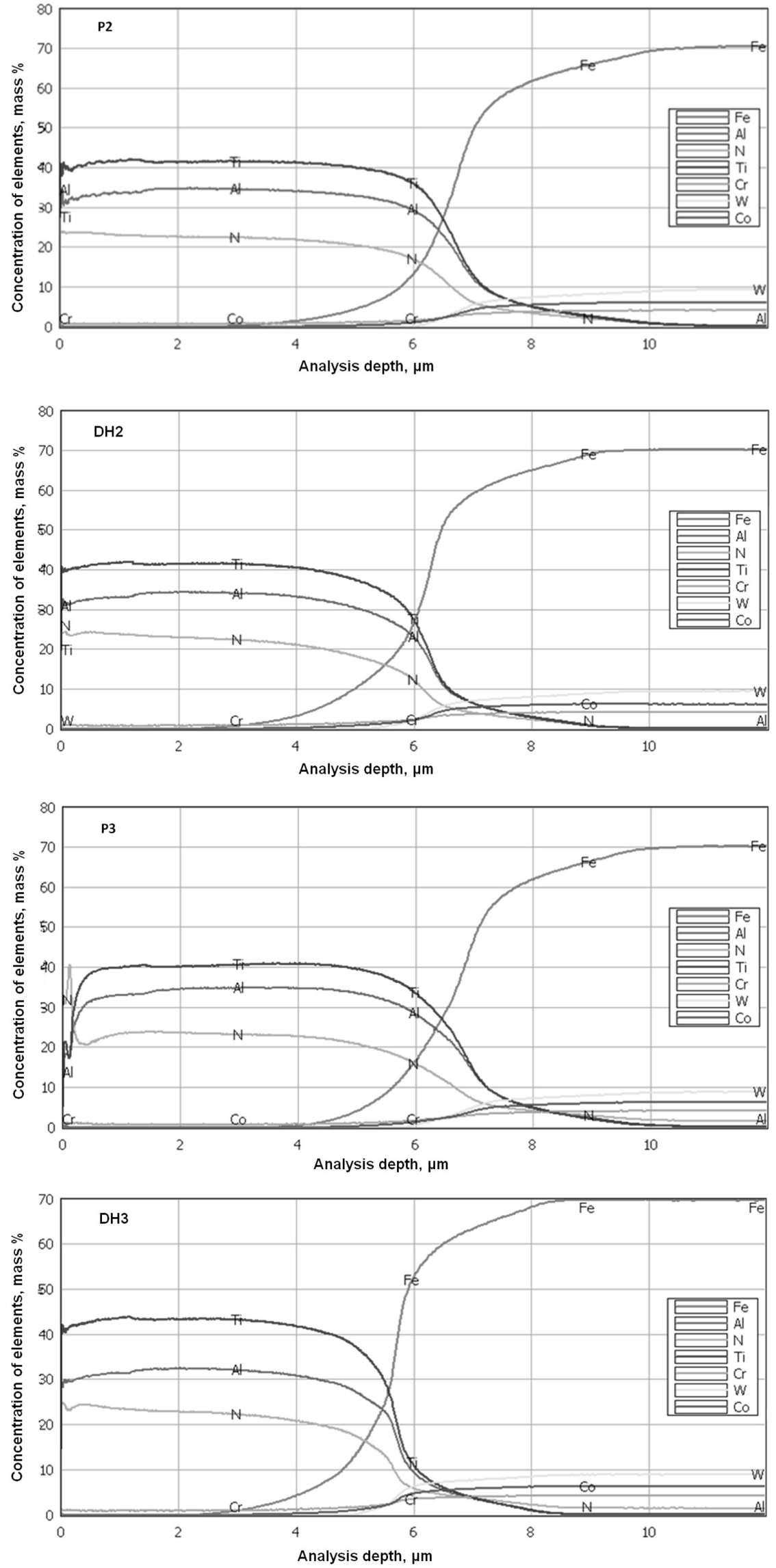

Fig. 1. Glow discharge optical emission spectroscopy (GDOES) depth profiles of TiAIN coating, a) TiAlN coating on the vacuum heat treated substrate (P2), b) TiAlN coating on the deep cryogenic treated substrate (DH2), c) TiAlN coating on the vacuum heat treated and plasma nitrided substrate (P3), d) TiAIN coating on the deep cryogenic treated and plasma nitrided substrate (DH3)

Bild 1. Tiefenprofil der Glow discharge optical emission spectroscopy (GDOES) der TiAIN Beschichtung, a) TiAIN Beschichtung auf dem klassisch thermisch behandelten Substrat (P2), b) TiAlN Beschichtung auf dem kryogenisch behandelten Substrat (DH2), c) TiAIN Beschichtung auf dem klassisch thermisch behandelten Substrat in Kombination mit Plasmanitrieren (P3), d) TiAIN Beschichtung auf dem kryogenisch behandelten Substrat in Kombination mit Plasmanitrieren (DH3) 

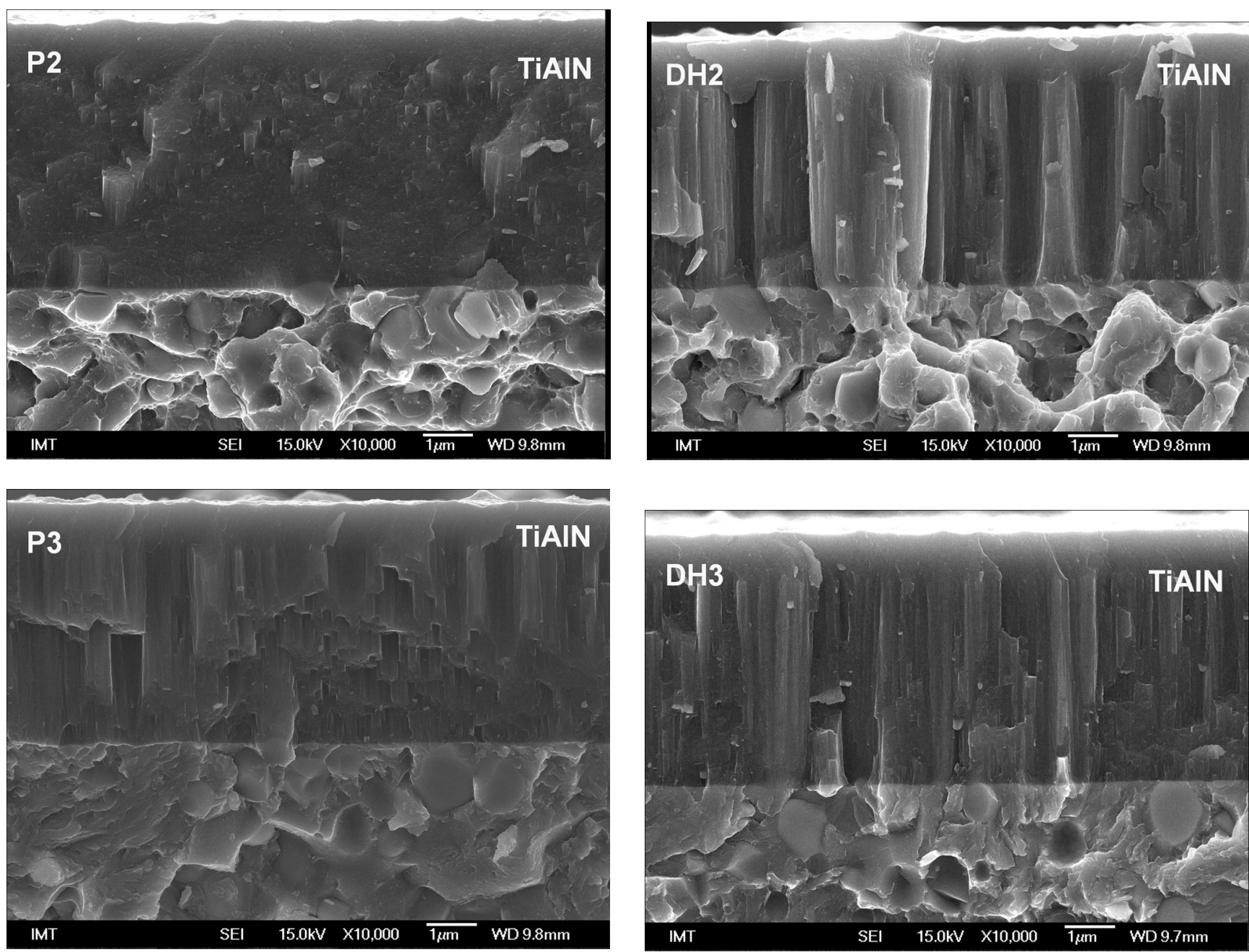

Fig. 2. Field-emission scanning electron microscope (FE SEM) micrographs of cross sections of specimens a) P2, b) $D H 2, c) P 3, d) D H 3$

Bild 2. FE SEM-Gefügeaufnahme an Proben a) $\mathrm{P} 2$, b) $\mathrm{DH}$ 2, c) $\mathrm{P} 3$, d) $\mathrm{DH} 3$

ing deposition, specimens were rotated in the double rotation mode. The deposition system CC800/9 has 4 unbalanced magnetron sources of TiAl. The power at sources was $8 \mathrm{~kW}$, the voltage was $400-500 \mathrm{~V}$, and the current was $10 \mathrm{~A}$.

\subsection{Coating characterization}

The compositional depth profile of TiAlN coating was analyzed glow discharge optical emission spectroscopy (GDOES) SPECTRUMAT 750 GDS, LECO. The microstructure of the TiAlN coating was analyzed on field-emission scanning electron microscope (FE-SEM), a JEOL JSM - 6500F, and by focused ion beam (FIB) analysis. A specimen for the focused ion beam was prepared and analyzed by using a dual beam microscope (ion and electron), Quanta 200 3D, FEI. Coatings were analyzed also with atomic force microscopy and of X-ray diffraction analysis.

Thickness of the coating was determined in accordance with the EN 1071-2, 2003 standard by using a Calotest. The microhardness of coatings was determined at load of $50 \mathrm{mN}$ by the Vickers method by means of a Fisherscope H100C. The scratch resistance was evaluated using a commercial scratch adhesion tester, CSEM REVETEST. Tests were carried out using a $200 \mu \mathrm{m}$ Rockwell C stylus with the scratching speed $10 \mathrm{~mm} / \mathrm{min}$, loading rate of $200 \mathrm{~N} / \mathrm{min}$, loading scale of 0-200 N, and scratch length $10 \mathrm{~mm}$. The critical loads, Lc, at which different coating failures occur, were determined by light optical microscopy, acoustic emission (AE) and tangential force $F_{t},\left(\mathrm{Lc}_{1}-\right.$ cracking of the coating, $\mathrm{LC}_{3}-$ flaking on the scratch edge, $\mathrm{LC}_{5}$ - total delamination of the coating).

\subsection{Tribological testing}

Wear resistance of the TiAlN coatings deposited on different substrates was investigated in the dry sliding wear condition using the "ball-on-flat" method and a CAMERON-PLINT TE77 machine, according to the ASTM G 133 standard. $\mathrm{A} \mathrm{Al}_{2} \mathrm{O}_{3}$ ball (Ø10 mm, $1200 \mathrm{HV}$ ) was used as a counterbody which was in contact with the tested specimen in a point. Testing parameters were as follows: normal force, $\boldsymbol{F}_{\mathrm{N}}=40 \mathrm{~N}$, pressure at the testing point, $p_{H}=1300 \mathrm{MPa}$, amplitude, $\boldsymbol{a}=2.4 \mathrm{~mm}$, frequency, $\boldsymbol{f}=5 \mathrm{~Hz}$ 


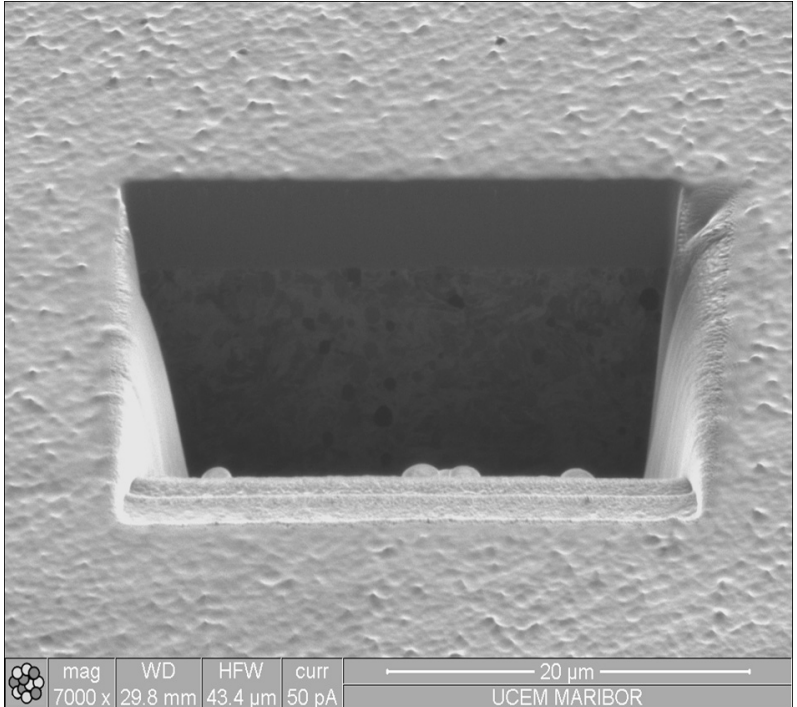

Fig. 3. Focused ion beam (FIB) cross section of TiAIN coated specimen

Bild 3. FIB-Querschnitt der TiAIN Beschichtung

and sliding velocity, $v_{\mathrm{s}}=0.024 \mathrm{~m} / \mathrm{s}$. The test time was 15 minutes (4500 cycles) which corresponded to a sliding distance of $22 \mathrm{~m}$. No abrasives were used during the test. The microabrasive wear resistance was tested by free-ball Calotest. A steel ball (100Cr6, $\varnothing 20 \mathrm{~mm}$, finely polished) was pressed with a preselected load twice on three specimens of each state, in the duration of $5 \mathrm{~min}$.

The diamond suspension in $3 \mu \mathrm{m}$ granulation was used as an abrasive in the amount of 12 drops per minute. Wear was estimated according to the volume of the crater formed during the process, and a 3D analysis of wear tracks was performed using a Taylor - Hobson Form Talysurf Series 2 profilometer, with lateral resolution of $0.3 \mu \mathrm{m}$ and vertical of $1 \mathrm{~nm}$.

\section{Results and discussion}

The properties of the high speed steel substrate after performed heat treatments were thoroughly investigated and the results were published elsewhere. The results showed that deep cryogenic treatment followed by plasma nitriding contributed to the increase in the adhesive and abrasive wear resistance of the PM S390 MC high speed steel [13].

\subsection{Chemical analysis and structural properties}

Glow discharge optical emission spectroscopy compositional depth profiles are shown in Fig. 1. The glow discharge optical emission spectroscopy spectra did not show any difference between coatings deposited onto the deep cryogenic treated substrate and onto the conventionally heat treated substrate, i.e. the PM S390 MC steel substrate. No significant differences were noted related to nitriding. The only thing to be noted is that the interface between the coating and the substrate is sharper for deep cryogenic treated substrates. The curves show that the diffusion of chemical elements was better in none deep cryogenic treated substrates.
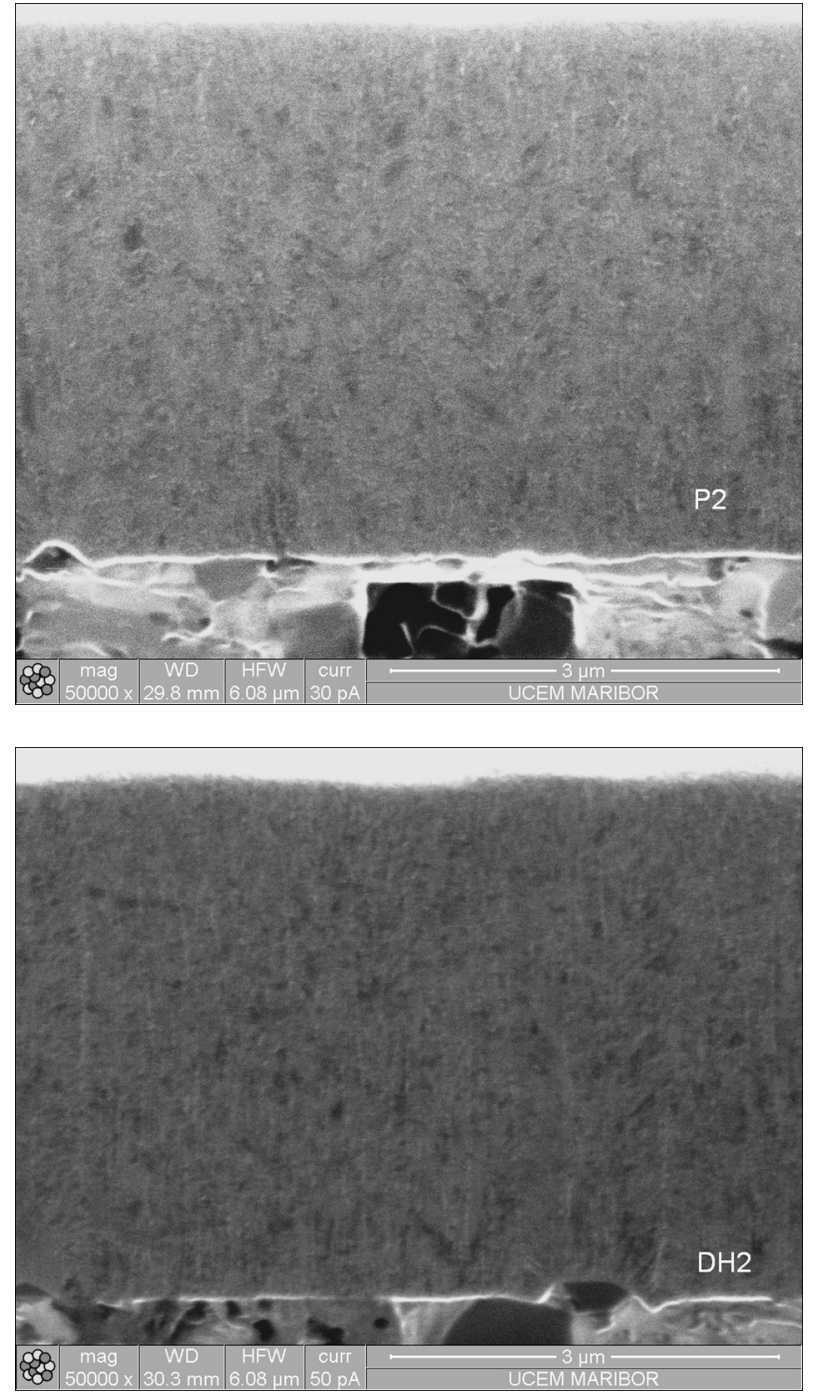

Fig. 4. Microstructure on focused ion beam cross section, a) TiAIN coating on the vacuum heat treated substrate (P2), b) TiAlN coating on the deep cryogenic treated substrate $(\mathrm{DH} 2)$

Bild 4. Gefüge des FIB-Querschnittes, a) TiAIN Beschichtung auf dem Vakuum thermisch behandeltem Substrat (P2), b) TiAIN Beschichtung auf dem kryogenisch behandelten Substrat ( $\mathrm{DH} 2)$

Figure 2 presents field-emission scanning electron microscope micrographs of transverse fractures of coated specimens where one can note the way how the coating growth depends on the substrate. Microstructure analysis of the substrate material showed the typical microstructure of the heat treated PM high speed steel. Spherical carbides of less than $1 \mu \mathrm{m}$ in diameter and evenly distributed in the martensite matrix were observed.

Analysis of coatings showed that the microstructure of the TiAlN coating is columnar on all substrates except in the P2 where the coating microstructure is fine-grained. After $3 / 4$ deposition time the coating was submitted to argon ion etching in order to obtain a compact top TiAlN layer with very fine grained microstructure. Subsequently, the deposition was resumed. Focused ion beam (FIB) analysis was carried out on the crater, Figure 3. 


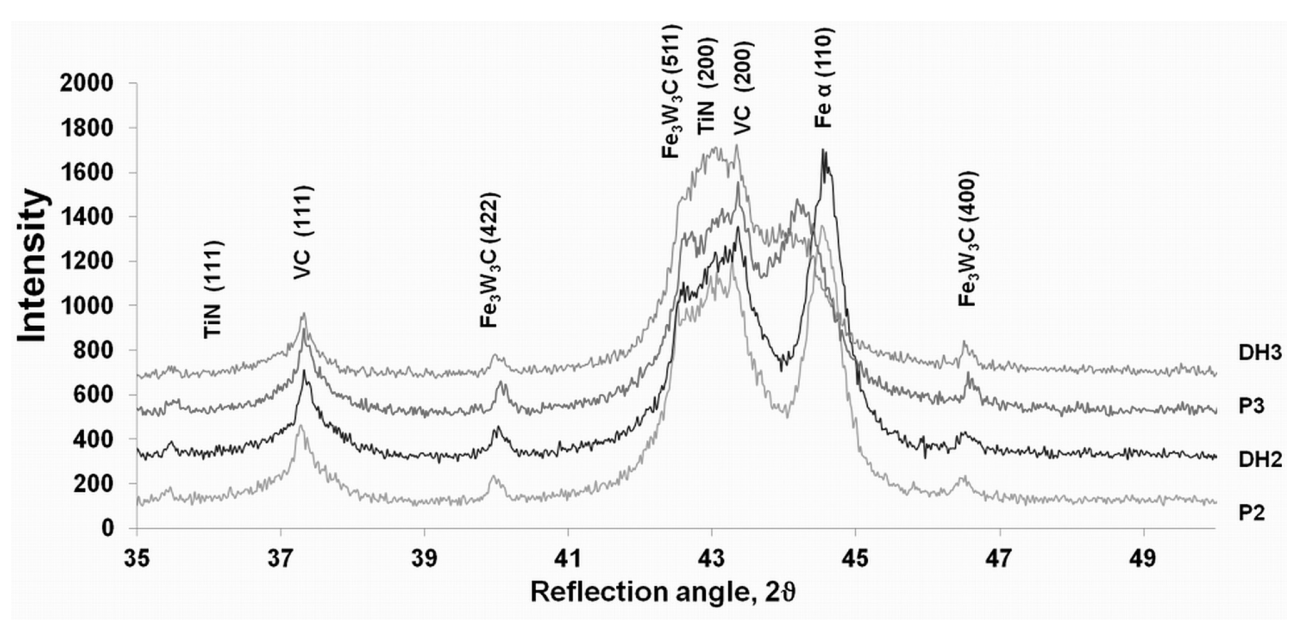

Fig. 5. X-ray diffraction spectra

Bild 5. Röntgenstrahlung-Diffraktionsanalyse

Focused ion beam analysis also showed the grained structure of the P2 specimen TiAlN coating and the coating columnar growth of the DH2 specimen, Fig. 4. The column width of the $\mathrm{DH} 2$ specimen is approximately $100 \mathrm{~nm}$.

Atomic force microscopy (AFM analysis) showed that the roughness of samples after PVD coating increased by approximately $70 \%$ compared to uncoated samples. The main cause is etching of the surface prior to coating. However it also increases due to the morphology of the coating and growth defects incorporated in it. The highest level of roughness was noted in specimens which had been nitrided before PVD coating although they were polished after nitriding. Deep cryogenic treated samples exhibit a lower level of roughness than the standard tempered samples. The morphology of the TiAlN coating could not be clearly seen in the atomic force microscopy images because there is a fine-grained layer on the surface, which had been applied after the second ion etching process. That is the reason why the effect of the substrate on the columnar growth of the coating could not be noted [5].

X-ray Diffraction (XRD analysis) showed that there was no difference between the coatings regardless of the substrate. This can be seen from the diffraction maxima of TiAlN reached at $42.597^{\circ}$, which are the same in all samples. From the x-ray diffraction spectra one can see that there are differences in diffraction maxima of carbides and martensite matrix of the high speed steel substrate. Figure 5 shows the spectra for all four specimens for $35-50^{\circ}$ angles.

The diffraction maximum at an angle of $44.677^{\circ}$ corresponds to the Fe matrix of martensite. One can note a difference in the height and width of the maximum, which indicated that the microstructure of martensite is small-grained, i.e. needles in martensite are finer in the deep cryogenic treated specimens, which is in agreement with the effects of deep cryogenic treatment $[5,9,10,13]$.

\subsection{Microhardness and coating adhesion}

The average thickness of the TiAlN coating measured in the Calotest was $6 \mu \mathrm{m}$ in all the tested samples. Measurement of the

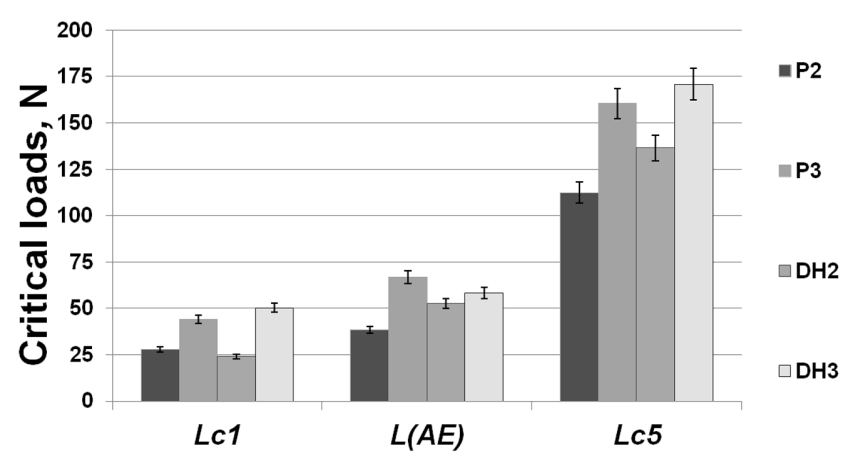

Fig. 6. Critical loads for investigated specimens

Bild 6. Kritische Belastung der untersuchten Proben

coating microhardness showed that the obtained values of hardness correspond to the expected values for the TiAlN coating of approx. $3500 \mathrm{HV}$. The scratch test showed that the deep cryogenic treatment has an influence on the critical loads at which cracks in the coating occur and at which the total coating delamination occurs, Figure 6.

In Figure 6 one can see that nitriding had the major effect on the start of the cracking phenomenon in the coating as the values of Lc1 critical load are significantly higher in the nitrided condition, and they are almost 50\% higher in the DH3 deep cryogenic treated and nitrided condition. For DH2 samples, the values of critical load at which start the coating delamination (Lc4) and load Lc5 at which the total coating delamination occure are higher than for P2 samples. The analysis of Lc5 forces causing the total coating delamination shows that deep cryogenic treatment and nitriding have resulted in improved adhesion between TiAlN coating and the substrate. The magnitude of DH2 force required to cause the total coating delamination is greater by almost $20 \%$ than that in the P2 condition. In nitrided conditions, the magnitude of force causing the total coating delamination is greater by $45 \%$ in the P 3 condition, and almost by $50 \%$ greater in the $\mathrm{DH} 3$ condition, than in the $\mathrm{P} 2$ condition. 


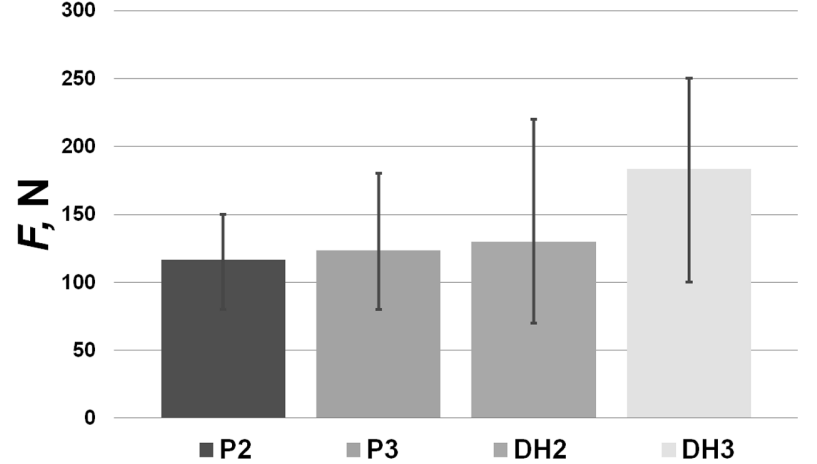

Fig. 7. Force required to break the coating in the "ball-on-flat" testing Bild 7. Benötigte kritische Kraft für die Beschichtungszerstörung mit der "Ball-on- Flat" Prüfung

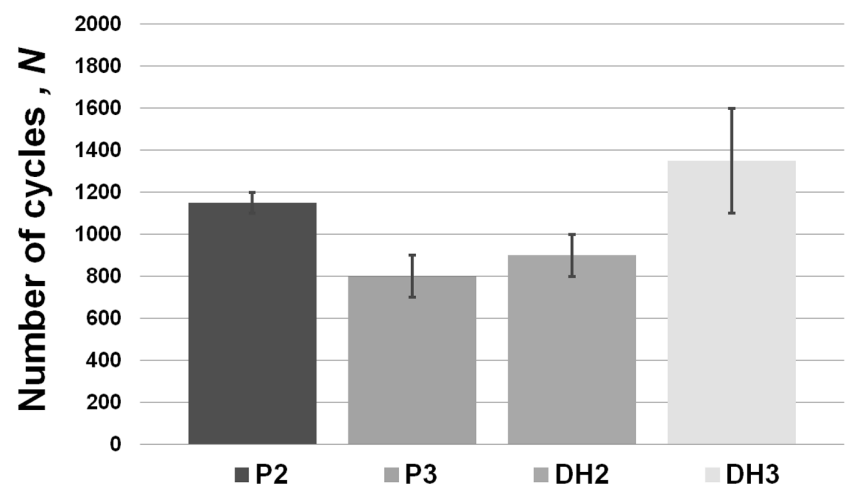

Fig. 8. Number of cycles before the coating is broken in the "ball-onflat" test

Bild 8. Zyklusnummern vor der Beschichtungszerstörung

The "ball-on-flat" test carried out to investigate the force required to break the coating exhibits wide dispersion of results, Figure 7.

The cause of result scattering is probably the small size of investigated area $(2.4 \mathrm{~mm}$ amplitude, contact with the counterbody in a point) which has been chosen randomly. Therefore, it is possible that some microdefect (crack or inclusion) is found in the investigated area of the substrate, which will result in inferior properties of the coating in some places. Nevertheless, the obtained results are in agreement with the scratch test results. The force required to break the coating was also stronger in this test for both deep cryogenic treated conditions. The strongest force required to break the coating was measured in the DH3 deep cryogenic treated and nitrided condition.

\subsection{Wear resistance}

The "ball-on-flat" method was used to investigate the resistance to dry sliding wear of the TiAlN coating and the substrate, since the coating was broken during testing and thus the substrate material also affected the results of wear. Figure 8 gives the number of cycles required to break the coating. It can be seen that DH3 samples endured the greatest number of cycles before the coating was broken.
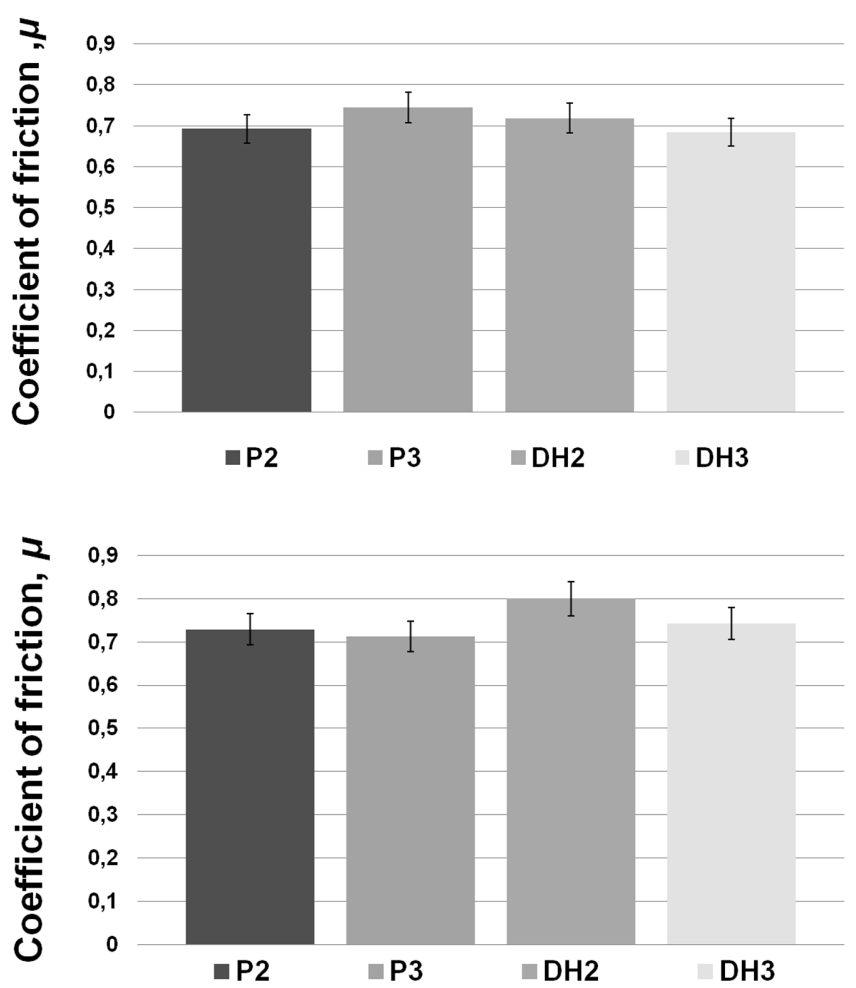

Fig. 9. Average friction coefficient during wear resistance testing with the "ball-on-flat" method: a) TiAIN coating, b) after the coating was broken

Bild 9. Durchschnittlicher Reibungskoeffizient bei der GleitverschleißPrüfung mit der "Ball-on-Flat" Methode: a) TiAIN Beschichtung, b) nach der Beschichtung

During the test, changes in the friction coefficients of the coating were noted. Figure 9 presents the average friction coefficient till the point when the TiAlN coating is broken and the average friction coefficient after that point.

The average friction coefficient before the coating has been broken is larger in deep cryogenic treated substrates in DH2 and DH3, Figure 9a. After the coating had been broken, the smallest value of friction coefficient was noted in the DH3 deep cryogenic treated and nitrided condition. It should be pointed out that the scattering of results was also noted in this test, as expected, because of the small size of the investigated area which had been selected randomly. In such a case, there is always a chance that there are some growth defects in the coating. After the predicted number of cycles of testing, the volume of wear track and the wear coefficient were determined by measuring wear tracks by means of a profilometer and an optical light microscope. The average results for the volume of removed material are presented in Figure 10.

Results of investigation show that the deep cryogenic treated conditions have better resistance to dry sliding wear than the conditions tempered in a standard way. The volume of removed material of the DH2 samples is smaller by approximately $30 \%$ than that of the P2 ones. The nitrided and deep cryogenic treated DH3 samples also had a 30\% smaller volume of removed material than the P3 ones. In this investigation, nitriding had minimum effect on the increase in the wear resistance, but there is a 
Table 3. Volume of removed material from the TiAIN coating, the substrate, and the total volume of removed material in microabrasive wear test

Tabelle 3. Das Verschleißvolumen der TiAIN Beschichtung, des Substrats und des gesamten Volumens nach der mikroabrasiven Prüfung

\begin{tabular}{lllrr}
\hline INVESTIGATED AREA & \multicolumn{4}{c}{ Volume, $\mu \mathbf{m}^{3}$} \\
\cline { 2 - 5 } & P2 & P3 & DH2 & DH3 \\
\hline A part of the coating crater & 2.098 .917 & 1.896 .246 & 1.926 .897 & 1.764 .624 \\
A part of the substrate crater & 360.655 & 469.610 & 168.365 & 130.532 \\
The whole crater & $\mathbf{2 . 4 5 9 . 5 7 2}$ & $\mathbf{2 . 3 6 5 . 8 5 5}$ & $\mathbf{2 . 0 9 6 . 2 6 2}$ & $\mathbf{1 . 8 9 5 . 1 5 6}$ \\
\hline
\end{tabular}

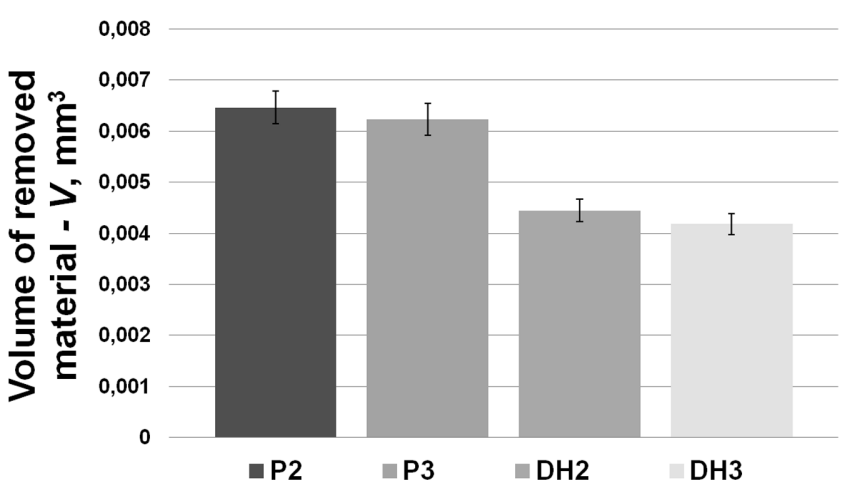

Fig. 10. Comparison of the volume of removed material in four different conditions during the "ball-on-flat" wear resistance testing

Bild 10. Vergleich des Gleitverschleiß-Materialvolumens

big difference between standard tempering and deep cryogenic treatment.

In microabrasive wear test, images of wear tracks were obtained by means of a optical light microscope. Using the program for determining the coating thickness, the volume of each crater was determined through the inner and outer diameters. Table 3 shows the volume of removed material from the coating, the substrate, and also the total volume of removed material.

Results of microabrasion wear testing of the TiAlN coating showed that the DH2 and DH3 deep cryogenic treated conditions had lost approximately $20 \%$ less material than the conditions treated in a standard way, Figure 11. The nitrided PH3 and DH3 samples are slightly better than the basic conditions. It can be concluded that the better resistance to microabrasion wear of the TiAlN coatings is obtained on the deep cryogenic treated substrates compared to the nitrided ones.

The profilometry of traces was conducted following the analysis of wear tracks. Figure 12 presents a 3D topography of wear tracks.

\section{Conclusions}

X-ray diffraction showed that the application of deep cryogenic treatment and of nitriding does not affect the growth and microstructure of the TiAlN coating. A detailed microstructure analysis performed using a field-emission scanning electron microscope and the focused ion beam analysis showed the granular growth of the coating only in the condition heat treated in a

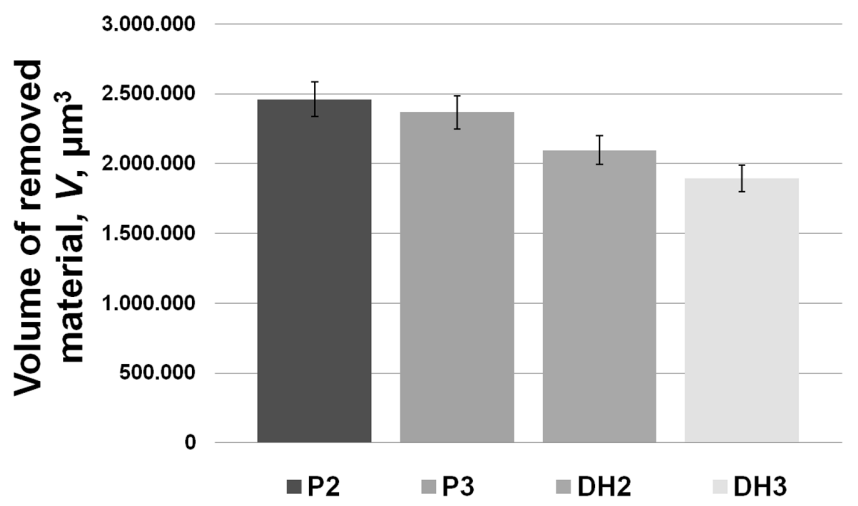

Fig. 11. Volume of the crater after microabrasion wear testing

Bild 11. Kratervolumen nach der Mikroabrasionsprüfung

standard way, while in all the other conditions the coating growth was columnar.

All four conditions of PM S390 MC steel heat treatment investigated here ensure very good adhesion of the substrate and the TiAlN coating. Deep cryogenic treatment does not result in a significant increase in the critical load for the total coating delamination (the increase is within the standard deviation), but nitriding following both the deep cryogenic treatment and the standard heat treatment has a considerable influence on the increase in the critical load for the total coating delamination.

In the conditions of sliding wear, i.e. dry abrasion, the deep cryogenic treatment had a significant influence on the increase in wear resistance, while nitriding did not influence the wear resistance greatly. TiAlN coatings applied on deep cryogenic treated substrates exhibited a significantly better wear resistance than the TiAlN coatings on conventionally heat treated substrates. This is true even in the conditions of abrasive wear (dry sliding wear) and microabrasive wear, regardless of the application of nitriding.

From the conducted investigations one can conclude that the deep cryogenic treatment and nitriding contribute to the improvement in the adhesive bonding between the high speed steel substrate and the TiAlN coating, which in turn contributes to improved wear resistance, particularly in the conditions of abrasive wear.

\section{Acknowledgements}

The authors thank Professor L. Curkovic, PhD, from the Faculty of Mechanical Engineering and Naval Architecture, University of 

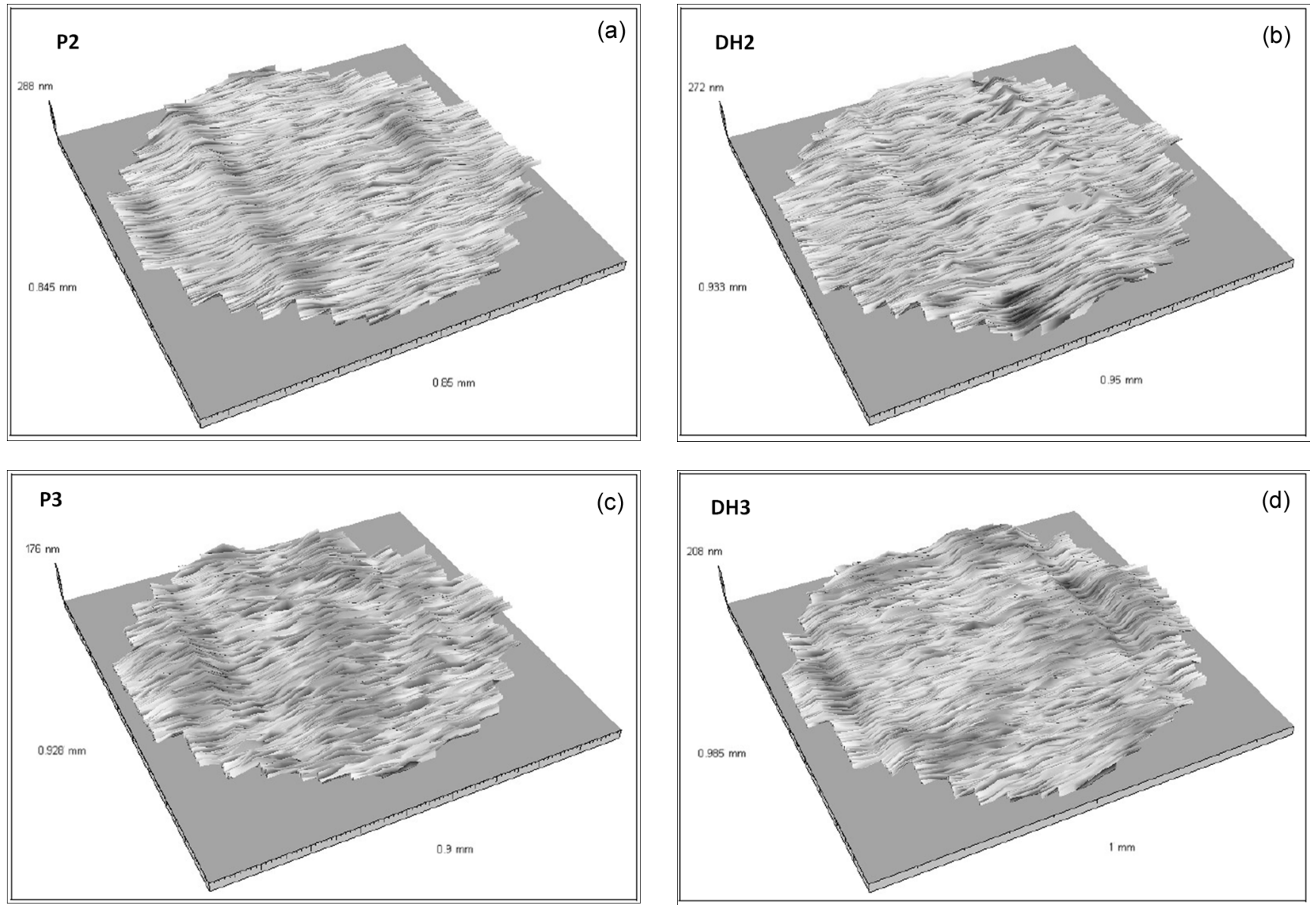

Fig 12. 3D topography of microabrasion wear tracks: a) P2, b) DH2, c) P3, d) $\mathrm{DH} 3$

Bild 12. 3D-Topographie der Verschleißspuren durch Mikroabrasion: a) P2, b) DH2, c) P3, d) DH3

Zagreb, for performing the glow discharge optical emission spectroscopy analysis and Professor F. Zupanic, PhD, from the Faculty of Mechanical Engineering, University of Maribor, for performing the focused ion beam analysis.

\section{References}

[1] K. Holmberg, A. Matthews, "Coatings Tribology”, Elsevier Science B. V., Amsterdam 1994.

[2] L. A. Dobrzanski, Journal of Materials Processing Technology 2001, 109, 44.

[3] S. Hogmark, S. Jacobson, M. Larsson, Wear 2000, 246, 20.

[4] M. Soković, B. Barišić, S. Sladić, Journal of Materials Processing Technology 2009, 209, 4207.

[5] S. Šolić, "Influence of the high speed steel microstructure on tribological properties of cutting tools", Doctoral Thesis, University of Zagreb, Croatia, 2011, (in Croatian).
[6] P. Panjan, M. Čekada, “Zaščita orodij s trdimi PVD - prevlekami”, Institut “Jožef Stefan”, Ljubljana 2005.

[7] M. Nordin, F. Ericson, Thin Solid Films 2001, 385, 174.

[8] P. Harlin, U. Bexell, M. Olsson, Surface Q Coatings Technology 2009, 203, 1748.

[9] A. Molinari, M. Pellizzari, et al., Journal of Materials Processing Technology 2001, 118, 350.

[10] V. Leskovšek, M. Kalin, J. Vižintin, Vacuum 2006, 80, 507.

[11] F. Meng, K. Tagashira, R. Azuma, H. Sohma, ISIJ International 1994, 34, 205.

[12] M. Godec, B. Šetina Batič, D. Mandrino, A. Nagode, V. Leskovšek, S. D. Škapin, M. Jenko, Materials characterization 2010, 61, 452.

[13] S. Šolić, F. Cajner, V. Leskovšek, MP Materials Testing 2012/ 10, 2012, 688-693.

[14] U. Helmersson, H. T. G. Hentzell, L. Hultman, M. K. Hibbs, J. E. Sundgren, Physical Sciences Center, AIP Conference Proceedings / Volume 149, 79-94.

Received in final form: May $27^{\text {th }} 2013$

T 168 